\title{
BUDIDAYA COLOCALLIA FUCHIPHAGA PENINGKATAN PRODUKTIVITAS IBU IBU RUMAH TANGGA DI KAMPONGE KECAMATAN BUNGORO KABUPATEN PANGKEP SULAWESI SELATAN
}

\author{
Nurdiyanti', Muhammad Wajdi², Nurul Magfirah ${ }^{3}$, Nurul Fadhilah ${ }^{4}$, Dian Safitiri $^{5}$ \\ 1,2,3,4,5Universitas Muhammadiyah Makassar, Makassar, Indonesia \\ 1*nurdiyanti@,unismuh.ac.id \\ 2muh.wajdi@unismuh.ac.id \\ 3nurul.magfirah@,unismuh.ac.id \\ nnurul.fadhulah@,unismuh.ac.id \\ 5dian.safitri@unismuh.ac.id
}

\begin{abstract}
Abstrak
Program Kemitraan Masyarakat budidaya Colocallia fuciphaga di Kamponge Kecamatan Bungoro Kabupaten Pangkep khususnya Ibu-Ibu Rumah Tangga yang menghabiskan sebagian besar waktunya untuk berkumpul bersama dengan tema pembahasan yang tidak ditentukan. Permasalahan utama yang dialami mitra yaitu; 1) Ibu-ibu rumah tangga yang menghabiskan sebagian besar waktunya untuk kumpul bersama dengan tema pembahasan yang tidak ditentukan, 2) Pengetahuan mitra masih terbatas mengenai cara memanfaatkan waktu kosong yang berproduktif dan menambah pendapatan, 3)Pengetahuan mitra masih terbatas mengenai teknik budidaya Colocallia Fuciphaga, 4) Rumah walet untuk budidaya Colocallia Fuciphaga memerlukan dana cukup besar. Metode Pelaksanaan barupa peninjauan lokasi, pengurusan perizinan pelaksaan kegiatan, pembuatan rumah walet, tahap budidaya, monitoring dan evaluasi, pembuatan laoran dan keberlanjutan program. Adapun target luaran yang akan dicapai bertambahnya pengetahuan masayarakat terkait budidaya Colocallia fuciphaga, menciptakan ibu-ibu rumah tangga yang produktif dan menambah pendapatan dari aspek ekonomi, menjadi pemasok utama dalam memproduksi sarang walet putih dan sustainable. Segala bentuk kegiatan ini akan dipublikasikan secara online pada media fajar online, dengan target luaran berupa laporan akhir dan artikel ilmiah dalam jurnal pengabdian STKIP Andi Matappa.
\end{abstract}

Kata Kunci: Community Budidaya, Colocallia fuchipafa, Produktivitas

\section{Pendahuluan}

Meningkatkan kualitas Kabupaten Pangkajene dan Kepulauan yang berbatasan dengan Kabupaten Barru di sebelah Utara, Kabupaten Maros disebelah Selatan, Kabupaten Bone disebelah Timur, dan di sebelah Barat berbatasan dengan Pulau Kalimantan, Pulau Jawa dan Madura, Pulau Nusa Tenggara dan Pulau Bali. Memiliki luas 12.362,73 km2, dengan luas wilayah laut 11.464,44 km2 dan luas wilayah daratan 898,29 km2, dengan panjang garis pantai $250 \mathrm{~km}$, yang membentang dari barat ke timur (Pangkepkab.go.id. 2018). Mayoritas masyarakat di

*Corresponding author: nurdiyanti@unismuh.ac.id 
Kabupaten Pangkep, sebagian besar bermata pencaharian sebagai nelayan dikarenakan wilayah lautnya lebih luas dibanding wilayah daratan. Sebagian besar Ibu-ibu rumah tangga istri seorang nelayan maupun istri dari seorang yang berprofesi bukan nelayan, menghabiskan waktunya untuk kumpul bersama dengan tema pembahasan yang tidak ditentukan. Sedangkan perekonomian masyarakat di Kabupaten ini dapat dikembangkan dengan melihat potensi yang ada. Membudidayakan Colocallia fuciphaga sebagai salah satu alternatif untuk meningkatkan produktivitas ibu-ibu rumah tangga yang menghabiskan sebagian besar waktunya untuk kumpul bersama dengan tema pembahasan yang tidak ditentukan.

Colocallia fuciphaga nama latin dari burung walet sarang putih, spesies ini mampu menghasilkan sarang berwarna putih dan paling disukai konsumen. Indonesia merupakan penyedia sarang burung walet dunia, ekspor sarang burung walet dilakukan ke berbagai negara di Asia dan Eropa, serta Australia dan Amerika Serikat. Colocallia Fuciphaga memiliki beberapa ciri khas yang tidak dimiliki oleh burung lain. Ciri khas tersebut diantaranya melakukan hampir segala aktivitasnya di udara, seperti makan dan bereproduksi sehingga burung walet ini disebut sebagai burung layang- layang. Selain itu, ciri yang paling khas dari jenis burung ini yaitu kemampuannya dalam menghasilkan sarang yang bernilai jual tinggi (Ayuti, dkk., 2016).

Salah satu syarat keberhasilan dalam pembudidayaan Colocallia fuciphaga adalah mengetahui habitat makro dari Colocallia fuciphaga. Habitat makro merupakan satu bagian yang penting untuk keberhasilan pembudidyaan burung walet. Berdasarkan studi habitat makro burung walet oleh Saepudin (2006), daerah perairan merupakan salah satu wilayah burung walet dalam mencari makan, daerah perairan yang menjadi lokasi perburuan serangga bagi burung walet adalah daerah seperti laut, danau, sungai, rawa dan kolam-kolam. Selain itu hal yang perlu diperhatikan adalah temperatur dan kelembaban, jenis dan struktur vegetasi serta jenis serangga yang terdapat di area tersebut.

Berdasarkan penelitian para ahli gizi, sarang walet mengandung glyco protein yang sangat bagus bagi perkembangan tubuh manusia. Departemen Kesehatan RI dalam penelitiannya juga mencatat bahwa kandungan sarang burung walet terdiri dari sebagian besar protein, karbohidrat, lemak. Sarang burung walet juga mengandung protein yang berbentuk glycoprotein yang merupakan komponen terbesar selain karbohidrat, lemak, dan air jumlahnya mencapai 50 persen (Mulyoko, 2010).

Sarang walet memiliki prospek dan tinggi dalam perdagangan yang sangat bagus untuk dikembangkan. Saat ini Indonesia merupakan sarang walet terbesar didunia. Mencapai lebih dari $78 \%$ sarang walet yang beredar di dunia berasal dari Indonesia. Sarang walet rumahan asal 
Indonesia menguasai hampir 99\% pasokan pasar dunia karena bentuknya yang lebih bersih, lebih putih, dan tidak terlalu tebal. Sementara pasar sarang walet hitam dipegang oleh Malaysia karena kualitasnya lebih baik dari pada sarang hitam yang diexspor oleh negara produsen lain. Sarang walet banyak diminta oleh importir terbesar saat ini yaitu Hongkong dan Amerika Serikat. Jangkauan pasar sarang walet asal Indonesia adalah Hongkong, China, Tiwan, Singapura, dan Kanada (Redaksi, 2014)

Produktivitas masyarakat di kampunge kecamatan bungoro kab. Pangkep mendukung adanya usaha burung walet. Karena adanya usaha burung walet dapat mengurangi pengangguran di Desa Simalinyang Kabupaten Kampar. Dengan adanya usaha burung walet ini maka bisa membantu untuk memenuhi kebutuhan masyarakat yang kurang memadai atau memiliki penghasilan yang sedikit (Nasir, 2011). Burung walet memiliki beberapa ciri khas yang tidak dimiliki oleh burung lain. Ciri khas tersebut diantaranya melakukan hampir segala aktivitasna di udaraseperti makan dan bereproduksi, sehungga burung walet sering disebut dengan burung layang-layang. Selain itu, ciri-ciri yang paling khas dari jenis burung ini yaitu kemampuannya dalam menghasilkan sarang yang bernilai jual tinggi. Indonesia merupakan penyedia sarang burung walet dunia. Ekspor sarang burung walet dilakukan ke berbagai negara di asia da eropa, serta di australia dan amerika serikat (Hendri, 2010).

Produk sarang burung walet dipengaruhi oleh berbagai faktor, salah satunya adalah faktor kondisi lingkungannya. Lingkungan burung walet terdiri habitat mikro dan makro. Habitat mikro burung walet adalah lingkungan di dalam gedung yang dapat di kondisikan sesuai kebutuhan seperti temperatur, kelembapan dan intensitas cahaya. Habitat makro adalah lingkungan walet di luar gedung tempat hidup dan mencari makan seperti ketinggian wilaya, suhu, dan kelembapan udarah, serta sumber air dan vegetasi sebagai penyedia pakan. Habitat makro tidak dapat dikondisikan layaknya habitat mikro, sehingga pembangunan gedung walet harus berada di daera yang tepat (Siti Arofah, 2016).

Berdasarkan pertimbangan studi habitat makro, penentuan lokasi untuk keberhasilan pembudidayaan burung walet terletak di daerah Kamponge, tepatnya di lahan kosong belakang rumah mitra. Jarak lahan tersebut dari laut sekitar $2 \mathrm{~km}$, dari sungai sekitar $10 \mathrm{~m}$, dan dari daerah persawahan kurang lebih $15 \mathrm{~m}$. Penentuan lokasi ini menjadi pertimbangan utama agar keberhasilan pembudidayaan sesuai dengan yang diharapkan. 


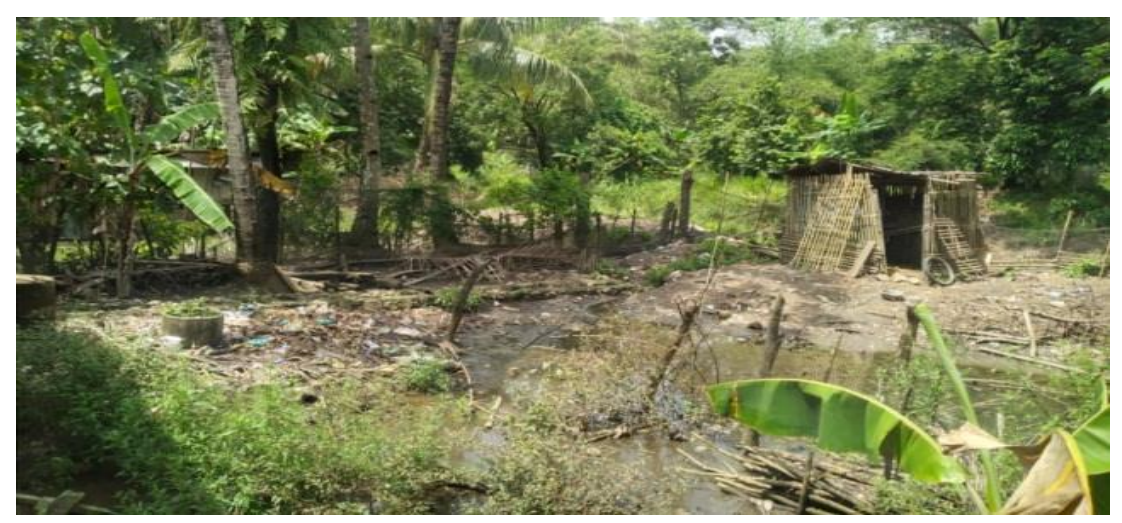

Gambar 1. Lahan mitra yang dapat digunakan

Mitra berprofesi sebagai ibu-ibu rumah tangga yang menghabiskan sebagian besar waktunya untuk kumpul bersama dengan tema pembahasan yang tidak ditentukan, dengan kata lain masyarakat yang tidak produktif secara ekonomi dikerenakan memiliki waktu luang yang dapat menambah pendapatankan hanya menghabiskan waktunya dengan kumpul bersama.

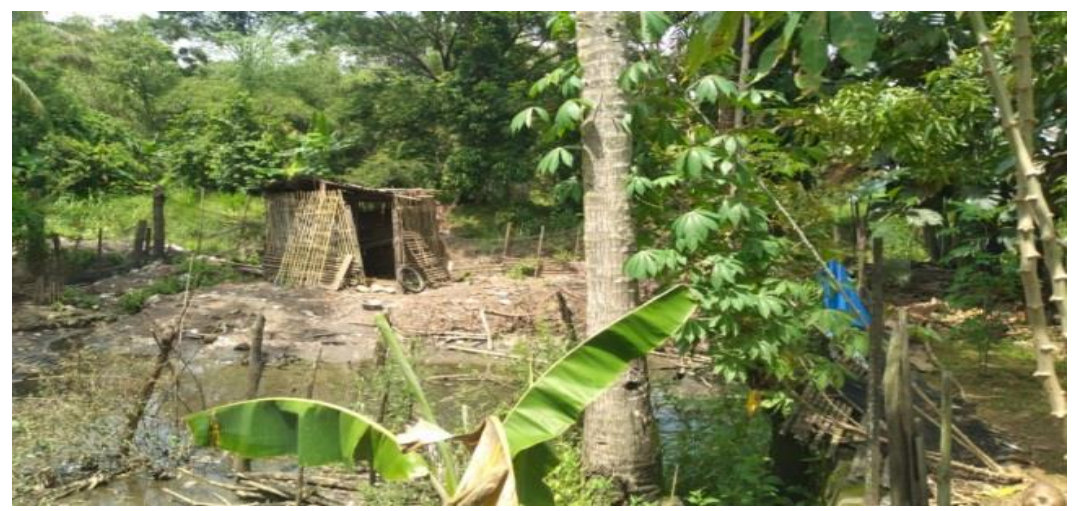

Gambar 2. Lahan mitra yang dapat digunakan

\section{Metode Pelaksanaan}

Pendampingan dan pelaksanaan kegiatan learning improvement ini diterapkan di SMP 1 Dolopo untuk semester gasal tahun ajaran 2019/2020. Perencanaan dan persiapan dalam pelaksanaan lesson study for learning community (LSLC) dilakukan dengan rincian sebagai berikut:

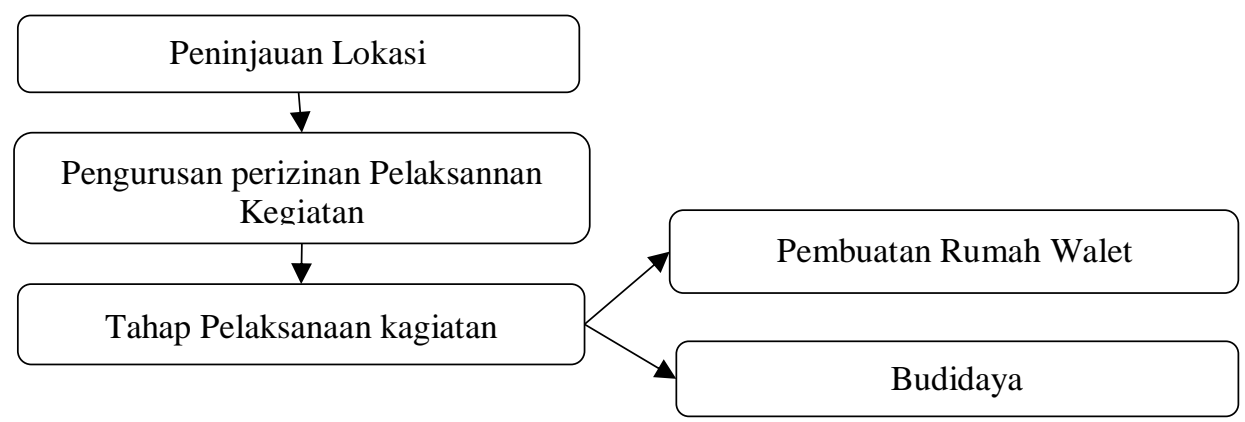

Diagram 1. Flow map Metode Pengembangan 


\section{Tahapan Pelaksanaan Kegiatan}

Sarana dan prasarana dalam menunjang terlaksananya kegiatan ini tentunya adalah rumah budidaya Colocallia fuciphaga dengan ukuran 3x6 m. Rumah budidaya berupa rumah walet yang berisi tweeter di tiap-tiap lubang untuk mengundang walet masuk. Ember sebagai wadah penyimpanan air dengan tujuan meningkatkan kelembapan dalam rumah walet. Adapun sarana dan prasarana lainnya yang dibutuhkan dalam proses kegiatan akan disesuaikan dengan situasi dan kondisi.

Budidaya Colocallia fuciphaga dalam program ini yaitu disajikan dalam flow map sistematis sebagi berikut:

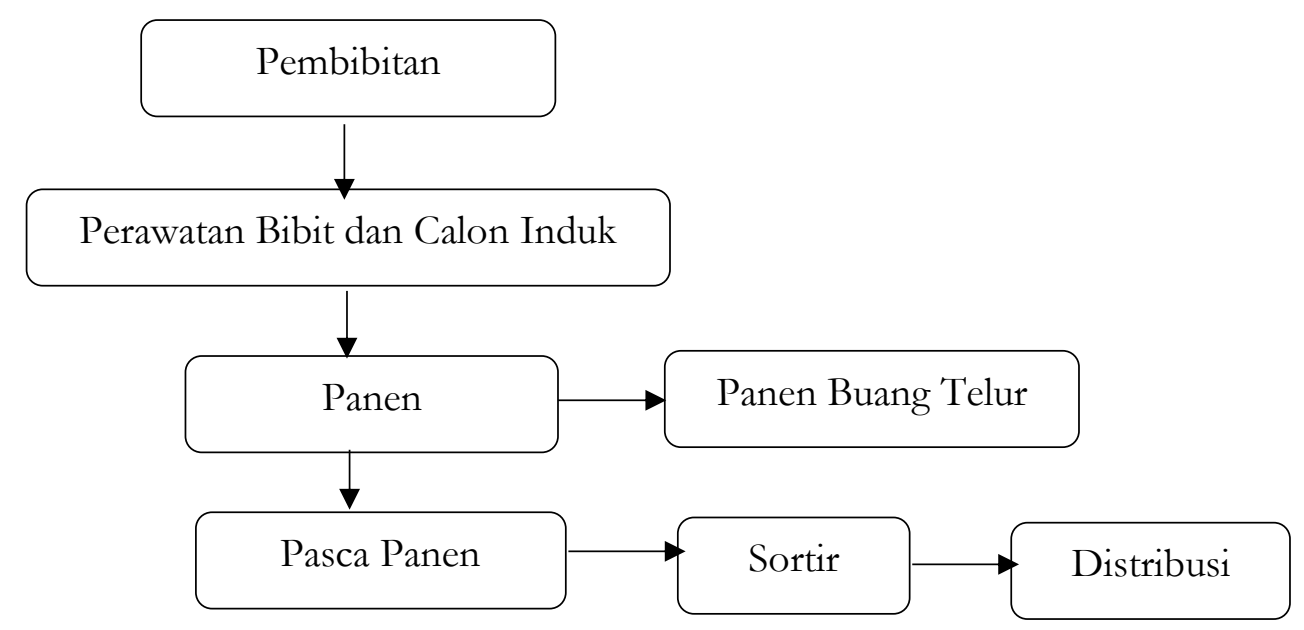

Diagram 2. Flow map Budidaya Colocallia fuciphaga

\section{Hasil dan Pembahasan}

Secara rinci keseluruhan kegiatan dan dokumentasi dijabarkan sebagai berikut:

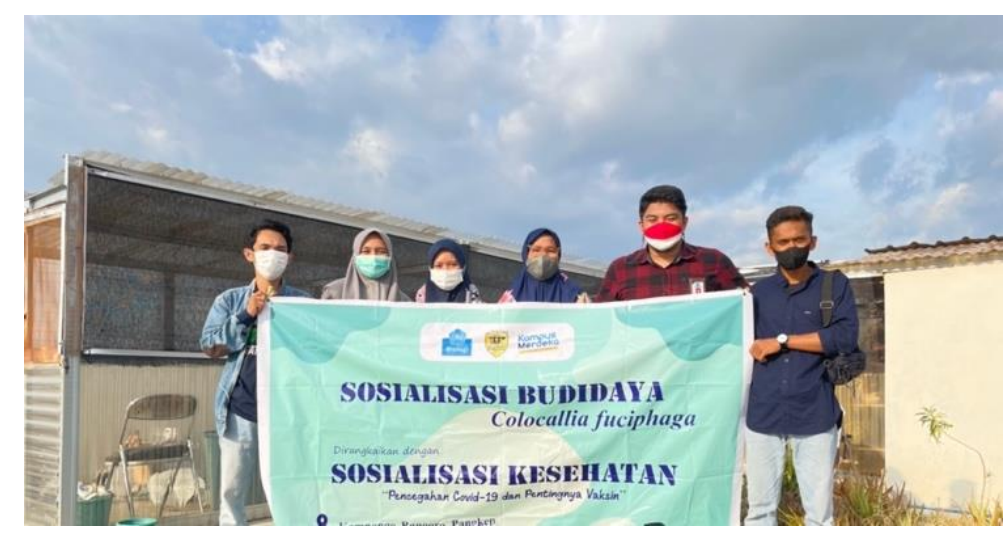

Gambar 3. Budidaya Colocallia fuciphaga 


\section{Sosialisasi Budidaya Colocallia fuciphag}

Kegiatan ini bertujuan untuk memberikan pengetahuan mengenai budidaya Colocallia fuciphaga yang sustainable. Tim penyelenggara memberikan pemaparan materi terkait cara budidaya Colocallia fuciphaga yang baik dan benar. Pada Gambar 5.1 Memperlihatkan kegiatatan Sosialisasi dilaksanakan di lokasi mitra.
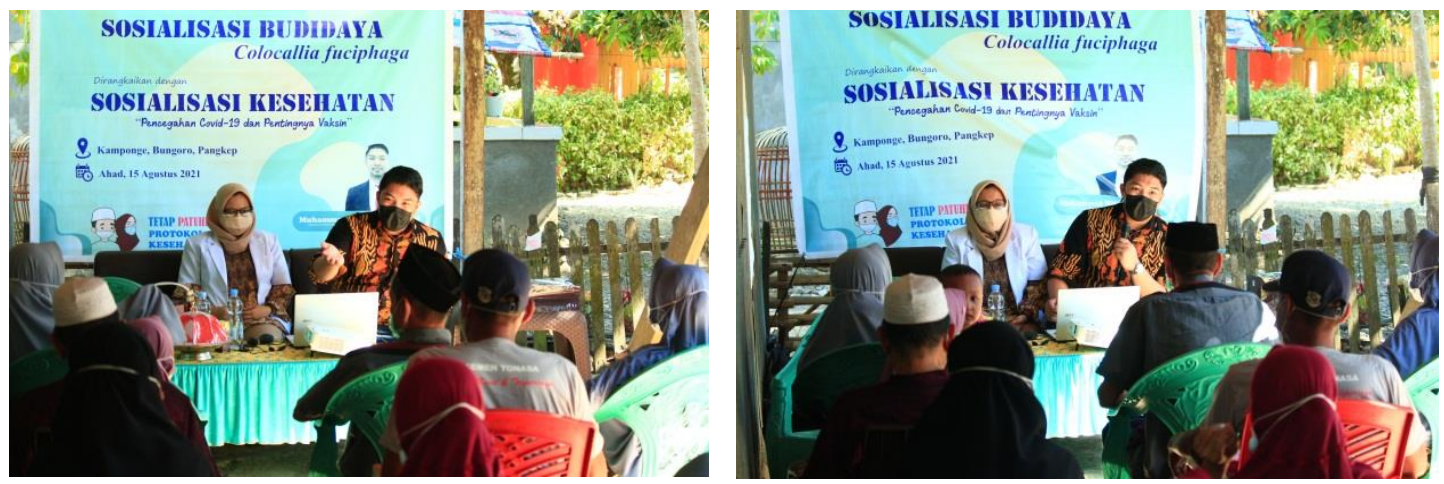

Gambar 4. Sosialisasi Colocallia fuciphaga

\section{Pelatihan Budidaya Colocallia fuciphaga}

Pelatihan budidaya Colocallia fuciphaga dilakukan dengan memberikan materi kepada warga, khususnya kelompok Ibu-Ibu Rumah Tangga yang nantinya akan mengelolah budidaya Colocallia fuciphaga tersebut. Dimulai dari sarana dan Prasarana apa yang akan dipersiapankan, cara pembibitan yang dilakukan dengan cara memancing walet (Colocallia fuciphaga) dengan menyiapkan tweeter di tiap-tiap lubang rumah yang berisikan rekaman suara burung walet. Rekaman ini diputar pada pukul 16.00 - 18.00 yaitu waktu burung walet kembali mencari makan dengan tujuan induk walet bersarang dalam rumah baru.

Perawatan Bibit dan Calon Induk, dalam budidaya walet, perlu disiapkan telur untuk memperbanyak populasi yang tentunya kan berpengaruh terhadap produksi sarang walet. Telur dapat diperoleh dari burung walet yang telah membuat sarang dan bertelur, disebut dengan "panen cara buang telur" sarang walet diambil kemudian telurnya ditetaskan dalam mesin penetas dan melakukan pemeliharan pada anak burung walet hingga burung walet siap terbang mengikuti walet dewasa.

Sarang walet dapat dipanen apabila keadaanya sudah memungkinkan untuk dipetik. Pemetikan sarang perlu dilakukan dengan ketentuan tertentu agar memnuhi mutu sarang yang baik. Teknik atau pola yang dalam budidaya walet ini yaitu "panen buang telur", cara ini dilaksanakan setelah membuat sarang dan bertelur dua butir, telur ditetaskan kemudian 
sarangnya diambil. Pola ini mempunyai keuntungan yaitu dalam dapat melakukan panen berkalikali dalam setahun. Hasil penen dibersihkan dengan memisahkan sarang walet yang bersih dengan yang kotor atau penyortiran kemudian dilakukan pendistribusian.

\section{Budidaya Colocallia fuciphaga}

a. Pembibitan Budidaya Colocallia fuciphaga

Pembibitan dilakukan dengan cara memancing walet (Colocallia fuciphaga) dengan menyiapkan tweeter di tiap-tiap lubang rumah yang berisikan rekaman suara burung walet. Rekaman ini diputar pada pukul 16.00 - 18.00 yaitu waktu burung walet kembali mencari makan dengan tujuan induk walet bersarang dalam rumah baru.

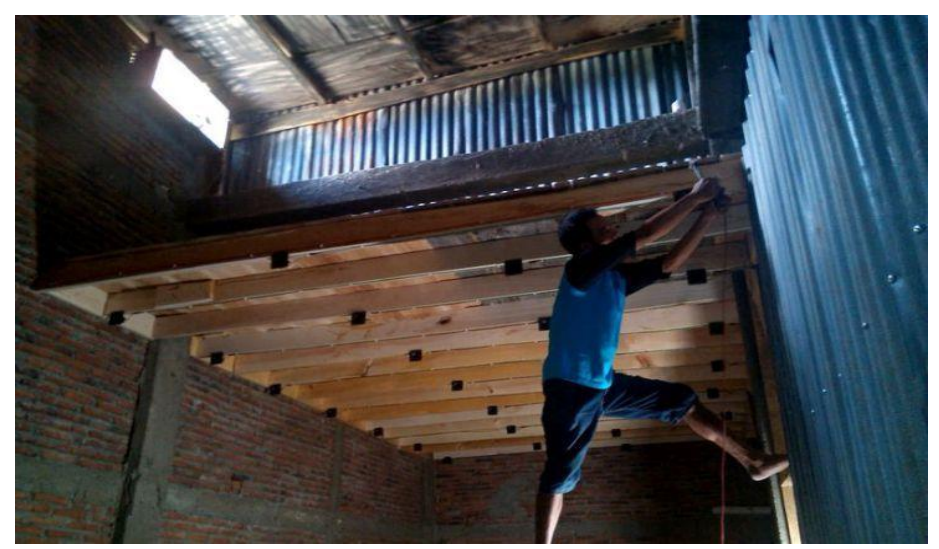

Gambar 5. Pembibitan Budidaya Colocallia fuciphaga

b. Perawatan Bibit dan Calon Induk

Dalam budidaya walet, perlu disiapkan telur untuk memperbanyak populasi yang tentunya kan berpengaruh terhadap produksi sarang walet. Telur dapat diperoleh dari burung walet yang telah membuat sarang dan bertelur, disebut dengan "panen cara buang telur" sarang walet diambil kemudian telurnya ditetaskan dalam mesin penetas dan melakukan pemeliharan pada anak burung walet hingga burung walet siap terbang mengikuti walet dewasa.

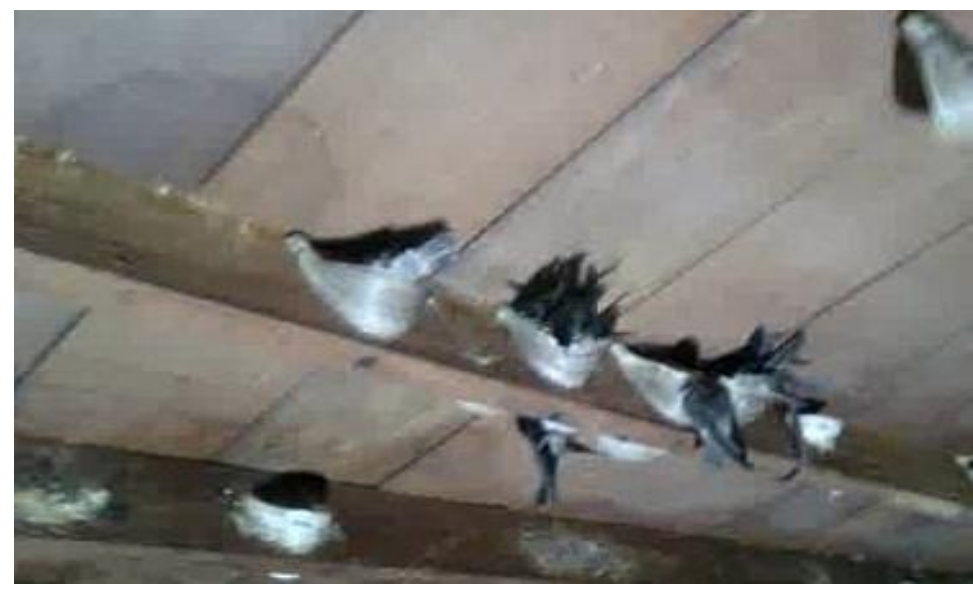

Gambar 6. Pembibitan Budidaya Colocallia fuciphaga 


\section{Kesimpulan}

Budidaya Colocallia fuciphaga dapat menciptakan ibu-ibu rumah tangga yang produktif dan menambah pendapatan dari aspek ekonomi, menjadi pemasok utama dalam memproduksi sarang walet putih dan sustainable.

\section{Referensi}

Ayuti, T., Garnida, D., Asmara, I, Y. 2016. Identifikasi Habitat dan Produksi Sarang Burung Walet (Collocalia fuciphaga) di Kabupaten Lampung Timur. Journal.unpad.ac.id. Pdf(online) diakses 02 April 2021.

Hendri Mulia. 2010. Cara Jitu Memikat Walet, Jakarta: Agromedia Pustaka, http://www.google.com/search?q=jenis+jenis+produktivitas

Mulyoko, Joko. 2010. Usaha Burung Walet di Universitas Pembangunan NasionalVeteran Jawa Timur Surabaya.

Nasir Salekat.2011. Membangun Rumah W alet Hemat Biaya, (Jakarta: Agromedia Pustaka.)

Pangkapkab.go.id. 2018. Geografi Kabupaten Pangkajene dan Kepualauan. https://pangkepkab.go.id/. Diakses 01 April 2021.

Redaksi Trubus. 2014. Panduan Praktis Sukses Memikat W alet, Jakarta: Penebar Swadaya. Saepudin, R. 2006. Studi Habitat Makro Burung Walet (Collocalia sp) di Kota Bengkulu. Jurnal Sains Peternakana Indonesia. Vol 1(1).

Siti Arofah. 2016. Budidaya Sarang Burung Walet di Gresik Universitas Aerlangga Surabaya 